\title{
Pengaruh Promosi dan Brand Image Terhadap Keputusan Nasabah dalam Memilih Pembiayaan Tabarok Pada BPRS Sarana Prima Mandiri Pamekasan
}

\author{
Luluk Farhatin Istiana1), Rudy Haryanto ${ }^{2)}$ \\ 1), 2)Institut Agama Islam Negeri Madura, Pamekasan, Indonesia \\ Corresponding author : rudyharyanto76@yahoo.co.id
}

\begin{abstract}
:
In the era of free trade, every company faces stiff competition. In order to succeed in a competitive business, businesses must offer the right promotion with standard service so as to create customer satisfaction which is an important indicator for measuring the performance of the company's business operations. This study uses a quantitative approach with a type of causal research (causality). The data analysis model used is multiple linear regression analysis. The results showed that, (1) from the $\mathrm{F}$ test result obtained a Fhitung value of 4,340 with a significant level of 0.016 (smaller than significant 0.05), while the Ftabel value of 1,703. (2) from the data analysis results it appears that the magnitude of Adjust R2 is 0.675 or $67.5 \%$. This means that $67.5 \%$ of the regression model capability in this study describes dependent variables. (3) from the test result t variable promotion (X1) obtained thitung of 1,980 with gis level. 0.000 . So that the decision of variable brand image is more influential (dominant) to the decision of tabarok customers in BPRS Sarana Prima Mandiri Pamekasan.
\end{abstract}

Keywords: Promotion, Brand Image, and Customer Decision.

\begin{abstract}
Abstrak:
Dalam era perdagangan bebas, setiap perusahaan menghadapi persaingan yang ketat. Agar bisa berhasil dalam bisnis yang kompetitif, pelaku bisnis harus menawarkan promosi yang tepat dengan pelayanan yang berstandart sehingga akan menciptakan kepuasan pelanggan yang merupakan indikator penting untuk pengukuran kinerja pengoperasian bisnis perusahaan. Penelitian ini menggunakan pendekatan kuantitatif. Metode pengumpulan data yang digunakan adalah penyebaran angket/kuesioner. Model analisi data yang digunakan adalah analisis regresi linier berganda. Hasil penelitian menunjukkan bahwa, (1) dari hasil uji $\mathrm{F}$ diperoleh nilai Fhitung sebesar 4,340 dengan tingkat signifikan sebesar 0,016 (lebih kecil dari signifikan 0,05), sedangkan nilai Ftabel sebesar 1,703. (2) dari hasil analisis data terlihat bahwa besarnya Adjust R2 adalah 0,675 atau 67,5\%. (3) dari hasil uji t variabel promosi (X1) diperoleh thitung sebesar 1,980 dengan taraf sig. 0,000 . Nilai t tabel untuk model regresi yaitu 1,969 . Hasil uji tersebut menunjukkan bahwa nilai signifikan $0,000<0,05$ dan nilai thitung 1,980 $>t$ tabel 1,969, sedangkan untuk variabel brand image (X2) diperoleh thitung sebesar 2,043 dengan taraf sig. 0,001 . Nilai ttabel untuk model regresi adalah 1,969. Sehingga keputusannya variabel brand image lebih berpengaruh (dominan) terhadap keputusan nasabah tabarok pada BPRS Sarana Prima Mandiri Pamekasan.
\end{abstract}

Kata Kunci: Promosi, Brand Image, dan Keputusan Nasabah. 


\section{PENDAHULUAN}

Dalam era perdagangan bebas, setiap perusahaan menghadapi persaingan yang ketat, yang menuntut perusahaan untuk selalu memperhatikan kebutuhan dan keinginan nasabah serta berusaha memenuhi harapan nasabah dengan cara memberikan pelayanan yang lebih memuaskan dari pada yang dilakukan oleh pesaing, sehingga akan memberikan manfaat seperti hubungan perusahaan dan nasabah menjadi harmonis, memberikan dasar yang baik untuk melakukan pembelian ulang, dapat mendorong terciptanya loyalitas nasabah, membentuk rekomendasi yang positif dari mulut ke mulut yang menguntungkan bagi perusahaan, reputasi perusahaan menjadi baik dimata nasabah, laba yang diperoleh dapat meningkat.

Agar bisa berhasil dalam bisnis yang kompetitif, pelaku bisnis harus menawarkan promosi yang tepat dengan pelayanan yang berstandart. Promosi adalah suatu usaha dari pemasaran dalam menginformasikan, mempengaruhi orang lain sehingga tertarik untuk melakukan transaksi atau pertukaran produk atau jasa yang dipasarkannya, serta mengingatkan kembali terhadap produk atau jasa yang ditawarkan bank. ${ }^{1}$

Seorang pemasar akan berhasil dalam komunikasinya jika mampu memberikan informasi benar. Respon atau tanggapan konsumen sebagai komunikan yang diharapkan oleh pemasar yaitu membentuk kesadaran informasi tertentu (kognitif), memberikan pengaruh untuk melakukan sesuatu berupa pembelian produk (afeksi) dan membentuk perilaku konsumen berupa pembelian ulang (behavior). ${ }^{2}$ Setiap produk menawarkan produk dan janji, hal ini akan mmberi pengaruh pada inat nasabah. Minat sebagai dorongan yaitu rangsangan internal yang kuat yang memotivasi tindakan, dimana dorongan ini dipengaruhi oleh stimulus dann perasaan positif akan produk.

Persaingan usaha yang semakin ketat dan penuh tantangan, menyebabkan lembaga keuangan syariah baik bank maupun non perbankan khususnya pihak manajemen harus mampu merancang dana menyusun strategi pemasaran yang mampu manjawab dan memenuhi tantangan pasar serta menjadikannya sebagai peluang pasar pada kancah persaingan bisnis baik masa sekarang ataupun masa yang akan datang. Perusahaan yang memiliki kapasitas untuk menyelesaikan persoalan pemasaran dan menemukan peluang-peluang yang terjadi di pasar lah yang bisa memenangkan persaingan. Kondisi dan situasi seperti ini, pihak manajemen mendorong agar lebih aktif berperan dan menyalurkan dan memperkenalkan produk-produknya supaya nasabah bisa dipengaruhi taerkait keputusan untuk memilih pembiayaan yang tersedia.

Kotler menyatakan sebuah brand harus memberikan sugesti tentang kualitas produk, mudah di ucapkan, tampil beda, dan jangan bertentang dengan pengertian dalam bahasa setepat, sehingga konsumen tertarik untuk melakukan kaputusan pembelian. ${ }^{3}$ Keputusan pembelian adalah proses dimana konsumen melewati lima tahap, yaitu pengenalanmasalah, pencarianinformasi, evaluasi alternative, keputusan pembelian, dan perilaku pasca pembelian actual dilakukan dan memiliki dampak yang lama.

Merek merupakan janji penjual untuk secara konsisten memberikan feature, manfaat dan jasa tertentu kepada pembeli. Merek merek terbaik memberikan jaminan kualitas, citra merek (brand image) merupakan sekumpulan asosiasi merek

${ }^{1}$ Ahmad Subagyo, Marketing in Business (Jakarta: Mitra Wacana Media, 2010), 132-134.

2 Fajar Laksana, Manajemen Pemasaran: Pendekatan Praktis (Yogyakarta: Graha Ilmu, 2008), 134.

${ }^{3}$ Buchari Alma, Manajemen Pemasaran dan Pemasaran jasa, (Bandung: Alfabeta, 2011), 157 
yang terbentuk dibenak konsumen. Konsumen yang terbiasa menggunakan merek tertentu cenderung memiliki konstitusi terhadap brand image atau hal ini disebut kepribadian merek (brand personality). ${ }^{4}$ Jadi kesadaran merek sebagai kemampuan yang dimiliki oleh pembeli potensial untuk mengenali dan mengingat bahwa merek adalah anggota dari kategori produk tertentu.

Brand image memberikan nilai strategis bagi perusahaan jika dikelola dengan benar. Berupa adaya penguragan biaya pemasaran, peningkatan nilai penjual, pangsa pasar, penciptaan kesadaran merek, peningkatan minat bagi pelanggan baru, pemberian kesempatan waktu bagi perusahaan untuk mengantisispasi kemungkinan adanya ancaman dari pihak pesaing.

Brand image merupakan suatu produk yang dikeluarkan oleh lembaga keuangan non syariah, seperti koperasi, KSU atau bank konvensional dijadikan sebagai pedoman oleh nasabah sebelum memberikan keputusan untuk memilih dan mempergunakan produk yang dikeluarkan oleh lembaga keuangan syariah. Dengan demikian perusahaan tersebut harus mampu membangun citra merek sebagai lembaga keuangan syariah yanga lebih baik dari pada lembaga keuangan konvensiaonal dangan memperi penawaran baru produk yang lebih bagus dan manfaat produk yang sesuai dengan kebutuhan dan keperluan masing-masing nasabah.

Sarana Prima Mandiri meluncurkan produk pembiayaan baru yang dinamakan pembiayaan "TABAROK" yaitu singkatan dari tanpa agunan dan barokah, yaitu pembiayaan yang memberikan kepada pengusaha kecil yang perputaran usahanya dalam 1 hari, artinya pendapatan yang diperoleh nasabah dari produk ini dapat ditentukan dalam1 hari (peracangan, mamin/ kuliner,penjual sayuran dll). ${ }^{5}$ Manajemen BPRS Sarana Prima Mandiri Pamekasan membuat terobosan baru dengan menghadirkan 2 unit mobil kas keliling untuk memberikan layanan kepada masyarakat. Layanan ini merupakan bagian dari strategi manajemen untuk lebih mendekatkan SPM dengan masyarakat secara langsung khususnya bagi penguasahapengusaha kecil di pelosok desa dan kecamatan. Dengan tagline BPRS SPM "bangngah oreng mekkasan" dan "TABAROK", maka seluruh stakeholder siap untuk memberikan layanan terbaiknya. Dari layanan mobil kas keliling ini, masyarakat bisa melakukan transaksi secara langsung baik untuk melakukan panarikan maupun penyetoran uang secara tunai. Sebagaimana diketahui bahwa BPRS Sarana Prima Mandiri Pamekasan telah memiliki produk unggulan yaitu produk pembiayaan TABAROK. Nasabah tabarok inilah yang banyak menikmati kehadiran mobil kas keliling SPM, karena target market dari pembiayaan ini memang menyasar kepada masyarakat kecil yang ada di pasar-pasar diseluruh pelosok. BPRS SPM juga membuka cabang bangkalan yang dimaksudkan untuk memperluas jaringan layanan BPRS SPM kepada masyarakat bangkalan. BPRS SPM berharap dengan keberadaannya akan menjadi pembuka jalan bagi SPM kedepan karena sesuai dengan rencana bisnis Bank, pada tahun 2018 ini juga BPRS SPM akan membuka jaringan kantor kas dan kantor cabang di beberapa wilayah baik di pamekasan maupun di bangkalan. ${ }^{6}$ Sehingga pembiayaan "Tabarok" yang ada di BPRS Sarana Prima Mandiri Pamekasan mengalami perkembangan dari segi jumlah nasabah, oleh peneliti disajikan dalam bentuk tabel berikut :

Tabel. 1.1

Jumlah Nasabah Tabarok pada BPRS Sarana Prima Mandiri Pamekasan

\begin{tabular}{|c|c|}
\hline Bulan & Jumlah Nasabah \\
\hline Juli & 450 \\
\hline
\end{tabular}

\footnotetext{
4 Freddy Rangkuti, The Power Of Brand TeknikMengelola Brand Equity dan Strategi Pengembangan Merek, (Jakarta, PT Gramedia Pustaka Utama, 2002), 43.

${ }^{5}$ Banksyariahspm.co.id

${ }^{6}$ Ibid
} 


\begin{tabular}{|c|c|}
\hline Agustus & 547 \\
\hline September & 668 \\
\hline
\end{tabular}

Sumber: BPRS Sarana Prima Mandiri Pamekasan (2019)

Dalam melakukan pemasaran (promosi) BPRS Sarana Prima Mandiri pamekasan ikut serta pada Bazar dan Expo Pamekasan sebagai upaya bank untuk lebih mengenalkan diri kepada masyarakat dengan menyediakan layanan produk "TABAROK" keikut sertaan tersebut merupakan bentuk promosi dari layanan Tabarok. Produk Tabarok disini sudah mempunyai tempat di hati masyarakat karena memiliki keunggulan salah satunya menerapkan akad mudharabah tanpa agunan dimana tidak semua lembaga keuangan memberikan layanan dengan akad mudharabah yang sangat berisiko ini.

\section{METODE PENELITIAN}

Penelitin ini merupakan jenis penelitian yang menggunakan pendekatan kuantitatif, yaitu penelitian dengan menggunakan analisis data statistic atau angkaangka yang dijumlahkan sebagai data yang kemudian dianalisis. Sedangkan jenis penelitiannya adalah kausal yaitu hubungan yang bersifat sebab akibat. ${ }^{7}$ Yaitu untuk mengukur besarnya pengaruh promosi dan brand image terhadap keputusan nasabah dalam memilih pembiayaan pada BPRS Sarana Prima Mandiri Pamekasan.

Variable yang digunakan pada penelitian ini yaitu promosi $\left(\mathrm{X}_{1}\right)$ dan brand image $\left(\mathrm{X}_{2}\right)$ sebagai variable independen/terikat dan keputusan pembelian (Y) sebagai variable dependen/bebas.

\section{A. Populasi dan Sampel}

Populasi yaitu keseluruhan objek yang akan diteliti. ${ }^{8}$ Populasi penelitian ini yaitu seluruh nasabah Tabarok BPRS Sarana Prima Mandiri Pamekasan yang berjumlah $668 .{ }^{9}$

Sampel yaitu sebagian dari populasi.10 Dalam penelitian ini peneliti menggunakan metode sampling incidental yaitu teknik pengumpulan sampel berdasarkan kebetulan, yaitu siapa saja yang secara kebetulan / incidental bertemu dengan peneliti dapat digunakan sebagai sampel, bila dipandang orang yang bersangkutan layak digunakan sebagai sumber data. ${ }^{11}$ Sampel yang digunakan peneliti yaitu nasabah tabarok, Dalam penelitian ini menggunakan cara perhitungan ukuran sampel dengan rumus dan tingkat ketepatan, kepercayaan dan keanekaragaman yang berbeda. Penentuan jumlah sampel ditentukan dengan menggunakan rumus Taro Yamane, dengan rumus: ${ }^{12}$

Keterangan:

$$
\mathrm{n}=\frac{N}{1+\mathrm{N}(\mathrm{e}) 2}
$$

n : Jumlah Sampel

$\mathrm{N} \quad$ :Jumlah Populasi

$\mathrm{e}^{2} \quad$ :Presisi yang ditetapkan/ Perkiraan tingkat kesalahan.

1 :Angka Konstanta

Besarnya populasi diketahui sebesar 668 anggota. Hal yang dijadikan pertimbangan dalam penentuan jumlah sampel, antara lain biaya dan waktu.

\footnotetext{
${ }^{7}$ Sugiyono, Metode Penelitian Kuantitatif, Kualitatif dan R\&D (Bandung: Alfabeta, 2009),37.

${ }^{8}$ Tim Penyusun Pedoman Penelitian Karya Ilmiah, Pedoman Penulisan Karya Ilmiah, 13.

${ }^{9}$ Banksyariahspm.co.id

${ }^{10}$ Fatati Nuryana, Statistik Bisnis Jilid 1 (Surabaya: Pena Salsabila, 2013), 40.

${ }^{11}$ Sugiyono, Metode Penelitian dan Pengembangan, 143.

12 Jonathan Sarwono dan Ely Suharyati, Riset Akuntansi Menggunakan SPSS (Yogyakarta: Graha Ilmu, 2010), 57.
} 
Peneliti menggunakan perkiraan tingkat kesalahan 5\% atau 0,05 dengan hitungan sebagai berikut:

$$
\begin{gathered}
\mathrm{n}=\frac{668}{1+668(0,05) 2} \\
=\frac{668}{2,67} \\
=250,187 \\
=250
\end{gathered}
$$

\section{B. Sumber Data}

Data merupakan salah satu komponen riset, artinya tanpa data tidak akan ada riset. ${ }^{13}$

Sumber data dalam penelitian ini yaitu:

1. Sumber data primer, adapun sumber data primer dalam penelitian ini yaitu diperoleh dari hasil angket.

2. Sumber data sekunder, adapun sumber data sekunder dalam penelitian ini yaitu diperoleh dari dokumentasi, observasi, buku dan jurnal.

\section{Instrumen Penelitian}

\section{Kuesioner (Angket)}

Penelitian ini menggunakan jenis kuesioner tertutup, yaitu pertanyaan yang diberikan kepada responden sudah dalam bentuk pilihan ganda. Responden tidak diberikan kesempatan untuk mengelurkan pendapat. Artinya angket yang diberikan kepada nasabah tabarok BPRS Sarana Prima Mandiri Pamekasan tersebut di dalamnya sudah disediakan jawaban, sehingga nasabah dapat langsung memilih dan memberikan tanda checklis $(\sqrt{ })$ atau centang pada jawaban yang telah tercantum di dalam angket. Peneliti menggunakan skala Likert dalam penelitian ini untuk mengetahui sikap responden.

Jawaban setiap item instrumen yang menggunakan skala likert peneliti memberikan pembobotan yang berupa kata-kata, antara lain:
Sangat setuju
(SS) diberi skor 5
Setuju
(S) diberi skor 4
Netral
(N) diberi skor 3
Tidak setuju
Sangat tidak setuju
(TS) diberi skor 2
(STS) diberi skor 1

\section{Dokumentasi}

Data yang kedua yaitu melalui data sekunder yang berupa dokumentasi, mencari data sekunder yang diperoleh dari berbagai sumber, baik dari literatur, artikel, data perusahaan, dan lain-lain yang dianggap relevan dengan penelitian. Tujuan penelitian kepustakaan ini adalah untuk memperoleh data teoritis untuk membangun landasan teori yang kuat guna mendukung penelitian ini.

\section{Pengumpulan Data}

Pada pembahasan ini, penulis uraikan tentang langkah-langkah dan teknik pengumpulan data, sebagai berikut:

\section{Studi Lapangan}

Peneliti terlibat secara langsung ke lokasi yang menjadi objek penelitian untuk menyebarkan kuesioner kepada responden, didalam hal ini adalah para nasabah Tabarok, yang akan dilakukan setiap waktu kerjanya BPRS Sarana Prima Mandiri Pamekasan yaitu kecuali hari sabtu dan minggu. Karena hari sabtu dan minggu merupakan hari libur.

\footnotetext{
${ }^{13}$ Husein Umar, Metode Penelitian Untuk Skripsi dan Tesis Bisnis Edisi Kedua, (Jakarta: Rajawali Pers, 2013), 49.
} 


\section{Studi Kepustakaan}

Mempelajari data berupa jurnal dan text book serta referensi yang relevan dari internet untuk mendapatkan landasan teoritis dalam pemecahan masalah.

\section{E. Analisis Data}

Analisis data merupakan proses mengatur urutan data, mengorganisasikannya ke dalam suatu pola, kategori dan satuan uraian dasar. ${ }^{14}$ Dalam penelitian ini analisis data dilakukan dengan menggunakan program SPSS (Statistical for The Social Sciences) versi 16. Adapun langkah-langkah dalam menganalisis data adalah sebagai berikut:

\section{Mencari Data Mentah}

Data mentah yang diperoleh merupakan data primer yaitu lagsung dari sumber yang diteliti berupa hasil angket dari nasabah tabarok pada BPRS Sarana Prima Mandiri Pamekasan.

\section{Statistik Deskriptif}

Untuk memberikan gambar demografi responden penelitian dan deskripsi mengenai variabel penelitian sejauh mana pengaruh promosi dan brand image terhadap keputusan nasabah memilih pembiayaan tabarok pada BPRS Sarana Prima Mandiri Pamekasan.

\section{Uji Kualitas Instrumen}

Berdasarkan instrumen peneltian yang digunakan, kualitas data yang dihasilkan dari penggunaan instrumen penelitian dapat dievaluasi melalui uji validitas dan reabilitas.

\section{a. Uji Validitas}

Uji validitas adalah untuk mengukur sah atau valid tidaknya suatu kuesioner. Pengujian validitas ini menggunakan alat bantu SPSS koefisien korelasi tiap item akan dibandingkan dengan $r$ tabel dengan taraf signifikan $5 \%$. Jika nilai korelasi suatu item / pertanyaan lebih kecil dari $r$ tabel maka pertanyaan tersebut tidak valid begitu pula sebaliknya, jika nilai korelasi suatu item / pertanyaan lebih besar dari $r$ tabel maka pertanyaan tersebut dikatakan valid. 15

\section{b. Uji Reliabilitas}

Reliabilitas adalah sesuatu instrumen cukup dapat dipercaya untuk digunakan sebagai alat pengumpul data karena instrumen tersebut sudah baik. Uji reabilitas adalah alat untuk mengukur suatu kuesioner yang merupakan indikator dari variabel kontruk. Pengukuran rebilitas dapat dilakukan dengan dua cara yaitu, (1) repeated measure atau pengukuran ulang dan, (2) one short atau pengukuran sekali saja. 16

SPSS memberikan fasilitas ntuk mengukur reabilitas dengan uji statistic cronbach alpha (a), sutu variaabel dikatakan, apabila :

Hasil $\mathrm{a} \geq 0,60=$ reliabel

Hasil a $<0,60=$ tidak reliabel

Pengujian realibilitas instrument dengan tehnik belah dua dari spearman brown (split half). Sebagai berikut:

Rumus spearman brown (split half):

Keterangan:

$$
\mathrm{r} 11=\frac{2 \cdot r b}{1+r b}
$$

\footnotetext{
${ }^{14}$ Misbahuddin dan Iqbal Hasan, Analisis Data Penelitian dengan Statistik ed. 2 (Jakarta: PT. Bumi Aksara, 2013), 32.

15 Imam Ghazali, Aplikasi Analisis Multivariate Dengan Program SPSS, (Semarang: Badan Penerbit Universitas Diponegoro, 2001), 33.

16 Purbaya Budi Santosa, Azhari, Analisis Statistic Dengan Microsof Excel Dan SPSS (Yogyakarta: ANDI, 2005), 25.
} 
r11 = koefisien reliabilitas seluruh item

$\mathrm{rb} \quad=$ koefisien produk moment antar belahan

\section{Uji Asumsi Klasik}

Uji asumsi klasik dilakukan untuk menilai baik atau tidaknya model regresi yang dikembangkan dalam penelitian antara lain sebagai berikut:

\section{a. Uji Multikolinieritas}

Uji Multikolinieritas bertujuan untuk menguji apakah model regresi ditemukan adanya kolerasi antar variabel bebas (independen). Model regresi yang baik seharusnya tidak terjadi kolerasi antara variabel bebas.

Untuk mendeteksi ada tidaknya multikolinieritas, penelitian ini menggunakan cara yakni dengan melihat nilai tolerance dan VIF.

\section{b. Uji Normalitas}

Uji normalitas dapat dilakukan dengan berbagai cara yaitu uji kertas peluang normal dan uji chi kudrat. Pengujian normalitas data ini lebih cepat dapat dkerjakan dengan komputer. ${ }^{17}$ Uji normalitas ini bertujuan untuk menguji apakah data yang digunakan dalam model regresi bedistribusi normal atau tidak.

\section{c. Uji Heteroskedastisitas}

Uji heteroskedastisitas disebut dengan kesalahan pengganggu. Dengan kata lain heteroskedastisitas merupakan variabel bebas, akan tetapi dengan varian dan untuk nilai X (nilai konstan) yang berbeda, dimana X merupakan variabel bebas. ${ }^{18}$ Uji ini bertujuan untuk menguji apakah model regresi yang digunakan terjadi ketidaksamaan antara varians dari residual satu pengamatan ke pengamatan yang lain. Alat yang digunakan untuk mendeteksi adanya ketidaksamaan varian tersebut adalah skala grafik.

\section{d. Uji Autokorelasi}

Uji autokarelasi menjadi uji apakah dalam suatu model regresi linear ada kolerasi antar kesalahan penganggu pada periode $t$ dengan kesalahan periode t-1 (sebelumnya). Jika terjadi korelasi, maka dinamakan problem autokorelasi.

Autokorelasi muncul karena observasi yang berurutan sepanjang waktu berkaitan satu sama lain. ${ }^{9}$ Masalah ini timbul karena residual (kesalahan penganggu) tidak bebas dari satu observasi ke observasi lainnya. Oleh sebab itu, uji asumsi klsik autokorelasi di lakukan untuk data yang memiliki seri (time series). ${ }^{20}$ Pada uji autokorelasi ini, peneliti menggunakan uji DurbinWaston (DW) dngan cara membandingkan DW hitung dengan DW tabelnya, derajat kepercayaan yang digunakan 5\%. Pengambilan keputusan ada tidaknya autokorelasi jika nilai DW terletak antar batas atas atau upper bound (du) dan (4-du), maka koefisien autokorelasi sama dengan nol, berarti tidak ada autokorelasi ${ }^{21}$

\section{Uji Hipotesis}

\section{a. Analisis Regresi Linear Berganda}

Penelitian ini menggunakan analisis regresi linear berganda. Analisis regresi linear berganda digunakan untuk meramalkan nilai variable terikat $(\mathrm{Y})$ apabila variable bebas minimal dua atau lebih. Analisis ini dimaksudkan untuk mengetahui besarnya pengaruh promosi dan brand image terhadap keputusan nasabah dalam memilih pembiayaan tabarok pada BPRS Sarana Prima Mandiri

\footnotetext{
17 Riduan, Dasar-Dasar Statistika (Bandung: Alfabeta, 2009), 187.

18 Ibid, 42

19 Mudrajat Kuncoro, Metodologi Kuantitatif, (Yogyakarta: Sekolah Tinggi Ilmu Managemen YKPN, 2011), 115.

20 Sunyoto, Metodologi Penelitian Akuntansi... 97

${ }^{21}$ Ghazali, Aplikasi Analisis... 61.
} 
Pamekasan dengan menggunakan rumus regresi linear berganda dapat dituliskan sebagai berikut:

Keterangan:

$$
\mathrm{Y}=\mathrm{a}+\beta 1 \mathrm{X} 1+\beta 2 \mathrm{X} 2+\mathrm{e}
$$

$\mathrm{Y}=$ Keputusan Pembelian (keputusan nasabah)

$\mathrm{X} 1=$ Promosi

$\mathrm{X} 2$ = brand Image

$\alpha=$ Konstanta

$\beta=$ Koefisien regresi

$\mathrm{e} \quad=$ Erorr $/$ epsilon $=$ kesalahan pengganggu

Koefisien arah regresi linear dinyatakan dengan huruf "b" yang juga dinyatakan perubahan rata-rata variabel Y untuk setiap variabel X sebesar satu bagian. Maksudnya bila b (+) maka Y akan mengalami kenaikan, bila b (-) maka Y akan mengalami penurunan.

Untuk melihat korelasi antar variabel dengan persamaan regresi di atas maka nilai a dan b harus di tentukan dahulu. Menurut Husaini Usman Dan Purnomo Setiady Akbar. Penentuan koefisien korelasi persamaan regresi dapat diketahui melalui melalui persamaan berikut:

$$
\begin{gathered}
\mathrm{b}=\frac{\sum X Y-\left(\sum X\right)\left(\sum Y\right)}{\sum X^{2}-\left(\sum X\right)^{2}} \\
\mathrm{a}=\frac{\left(\sum Y\right)\left(\sum(X)^{2}\right)-\left(\sum X\right)\left(\sum X Y\right)}{n \sum X^{2}-\left(\sum X\right)^{2}}
\end{gathered}
$$

Jika 'b' sudah di hitung terlebih dahulu, maka 'a' dapat di hitung dengan rumus :

$$
\mathrm{a}=\mathrm{Y}-\mathrm{Bx}
$$

\section{b. Uji F (Uji Simultan)}

Pengujian ini melibatkan semua variabel bebas terhadap variabel terikat dalam menguji data ada tidaknya pengaruh yang signifikan secara bersamasama. ${ }^{22}$ Adapun langkah-langkah pengujian signifikan secara simultan adalah sebagai berikut :

1) Membuat formulasi hipotesis,

Ho : $\mathrm{p}-0$

Ha: $p \neq 0$

2) Menentukan taraf signifikan dan nilai $F_{\text {tabel, }}$

Pada pengujian ini menggunakan taraf signifikan $5 \%$

Nilai $F_{\text {tabel }}=F(\alpha)(\mathrm{dka}, \mathrm{dkb})$

$\mathrm{dka}=$ jumlah variabel bebas (pembilang)

$\mathrm{dkb}=\mathrm{n}-\mathrm{m}-1$ (penyebut)

3) Menentukan nilai $F_{\text {hitung, }}$

4) Membuat keputusan berdasarkan criteria,

Jika $F_{\text {hitung }}>F_{\text {tabel }}$ maka Ho ditolak Ha diterima, Jika $F_{\text {hitung }}<F_{\text {tabel, }}$ maka Ho diterima dan Ha ditolak.

5) Membuat keputusan yaitu menerima tau menolak Ho

22 Iqbal Hasan, Analisis Data Penelitian Dengan Statistik (Jakarta : Bumi Aksara, 2010), 107. 


\section{c. Uji t (Uji Individual/Parsial)}

Pengujian individual (uji t) digunakan untuk menguji apakah nilai koefisien regresi mempunyai pengaruh yang signifikan secara sendiri-sendiri terhadap variabel terikat. Uji ini menggunakan uji t yaitu :23

Keterangan :

$$
\mathrm{t}=\frac{b i}{S b i}, \quad \mathrm{i}=1,2,3, \ldots \ldots .
$$

$\mathrm{B}_{\mathrm{i}} \quad=$ koefisien $\mathrm{b}$ ke $-\mathrm{i}$

Sbi = standart eror koefisien $b$ ke-i

$\mathrm{B}^{\mathrm{i}} \quad=$ merupakan penduga dari $\beta_{\mathrm{i}}$

Adapun keputusan yang dapat diambil berdasarkan kriteria sebagai berikut :

a) Apabila nilai $t_{\text {hitung }}<t_{\text {tabel }}$, maka Ho diterima. Artinya, variabel independen tidak meberikan pengaruh yang signifikan terhadap variabel dependen.

b) Apabila nilai $t_{\text {hitung }}>t_{\text {tabel }}$, maka Ha diterima. Artinya, variabel independen memberikan pengaruh yang signifikan terhadap variabel dependen.

\section{d. Koefisien Determinasi}

Koefisien determinasi merupakan bagian dari keragaman total variabel terikat $\mathrm{Y}$ yang dapat diterangkan atau diperhitungkan oleh keragaman variabel bebas $X$, sehingga koefisien determinasi adalah kemampuan variabel $X$ mempengaruhi variabel $\mathrm{Y}$, semakin besar koefisien determinasi menunjukkan semakin baik variabel $\mathrm{X}$ menerangkan variabel $\mathrm{Y}$.

Pada penelitian ini akan menunjukkan dan menjelaskan hasil berkenaan seberapa besar pengaruh variabel $\mathrm{X}_{1}$ (promosi) dan $\mathrm{X}_{2}$ (brand image) terhadap variabel $Y$ (keputusan nasabah). Koefisien determinasi digunakan untuk menunjukkan besarnya sumbangan $Y$ terhadap X. Secara statistik, koefisien determinasi dianggap sebagai korelasi pangkat dua :

$$
\mathrm{R}^{2}=(\text { korelasi) })^{2} \text { atau } \mathrm{R}^{2}=\mathrm{r}^{2}
$$

\section{HASIL DAN PEMBAHASAN}

Berdasakan penelitian "Pengaruh Promosi dan Brand Image Terhadap Keputusan Nasabah dalam memilih pembiayaan Tabarok pada BPRS Sarana Prima Mandiri Pamekasan" diperoleh informasi umum sebagai berikut:

\section{Tabel 1.1}

Hasil Uji Validitas Tiap Item Pernyataan Variabel Promosi (X1), Variabel Brand Image (X2) dan Keputusan Nasabah (Y)

\begin{tabular}{|c|c|c|c|}
\hline Item & Koefisien Korelasi & rtabel & Validitas \\
\hline \multicolumn{3}{|c|}{ Promosi (X1) } \\
\hline $\mathrm{X} 1.1$ & 0,500 & 0,1241 & Valid \\
\hline $\mathrm{X} 1.2$ & 0,654 & 0,1241 & Valid \\
\hline $\mathrm{X} 1.3$ & 0,658 & 0,1241 & Valid \\
\hline $\mathrm{X} 1.4$ & 0,633 & 0,1241 & Valid \\
\hline $\mathrm{X} 1.5$ & 0,635 & 0,1241 & Valid \\
\hline $\mathrm{X} 1.6$ & 0,635 & 0,1241 & Valid \\
\hline $\mathrm{X} 1.7$ & 0,531 & 0,1241 & Valid \\
\hline $\mathrm{X} 1.8$ & 0,579 & 0,1241 & Valid \\
\hline \multicolumn{4}{|c|}{ Brand Image $\mathbf{~ X 2 )}$} \\
\hline $\mathrm{X} 2.1$ & 0,574 & 0,1241 & Valid \\
\hline $\mathrm{X} 2.2$ & 0,653 & 0,1241 & Valid \\
\hline $\mathrm{X} 2.3$ & 0,676 & 0,1241 & Valid \\
\hline $\mathrm{X} 2.4$ & 0,460 & 0,1241 & Valid \\
\hline $\mathrm{X} 2.5$ & 0,580 & 0,1241 & Valid \\
\hline
\end{tabular}

23 Bilson Simamora, Riset Pemasaran, Falsafah, Teori, Dan Aplikasi, (Jakarta : PT Gramedia Pustaka Utama,2004), 346. 


\begin{tabular}{|c|c|c|c|}
\hline X2.6 & 0,532 & 0,1241 & Valid \\
\hline X2.7 & 0,698 & 0,1241 & Valid \\
\hline X2.8 & 0,667 & 0,1241 & Valid \\
\hline X2.9 & 0,628 & 0,1241 & Valid \\
\hline X2.10 & 0,266 & 0,1241 & Valid \\
\hline \multicolumn{4}{|c|}{ Keputusan Nasabah (Y) } \\
\hline Y1 & 0,547 & 0,1241 & Valid \\
\hline Y2 & 0,564 & 0,1241 & Valid \\
\hline Y3 & 0,598 & 0,1241 & Valid \\
\hline Y4 & 0,509 & 0,1241 & Valid \\
\hline Y5 & 0,778 & 0,1241 & Valid \\
\hline Y6 & 0,764 & 0,1241 & Valid \\
\hline Y7 & 0,559 & 0,1241 & Valid \\
\hline Y8 & 0,559 & 0,1241 & Valid \\
\hline
\end{tabular}

Sumber: Data Primer yang diolah, tahun 2019

Tabel 1.2

Hasil Uji Reliabilitas Tiap Item Peryantaan

\begin{tabular}{|c|c|c|}
\hline Variabel & $\begin{array}{c}\text { Nilai Cronbach } \\
\text { Alpha }\end{array}$ & Keterangan \\
\hline Promosi (X1) & 0,750 & Reliabel \\
\hline Brand Image (X2) & 0,784 & Reliabel \\
\hline Keputusan Nasabah (Y) & 0,756 & Reliabel \\
\hline
\end{tabular}

Sumber: Data primer yang diolah, tahun 2019

Dari keterangan tabel diatas dapat diketahui bahwa masing-masing variabel memiliki cronbach's alpha $>0,60$. Dengan dimikian variabel promosi, kualitas layanan dan kepuasan nasabah dapat dikatakan reliabel.

Tabel 1.3

Hasil Uji Multikolinieritas

\begin{tabular}{|c|c|c|c|}
\hline \multicolumn{4}{|c|}{ Coefficients $^{a}$} \\
\hline \multirow{2}{*}{\multicolumn{2}{|c|}{ Model }} & \multicolumn{2}{|c|}{ Collinearity Statistics } \\
\hline & & Tolerance & VIF \\
\hline \multirow[t]{3}{*}{1} & (Constant) & & \\
\hline & $\mathrm{X} 1$ & .979 & 1.022 \\
\hline & $\mathrm{X} 2$ & .979 & 1.022 \\
\hline
\end{tabular}

a. Dependent Variable: Y

Sumber: Data primer yang diolah, tahun 2019

Tabel diatas menunjukkan bahwa nilai tolerance variabel promosi (X1) sebesar 0,979 $>0,10$ dan brand image (X2) sebesar 0,979 $>0,10$ serta nilai VIF masing-masing VIF yaitu 1,022 < 10 dan 1,022 < 10 sehingga dapat disimpulkan bahwa antar variabel bebas tidak terjadi multikolinearitas. 
Tabel 1.4

Hasil Uji Autokorelasi

Model Summaryb

\begin{tabular}{|l|r|r|r|r|r|}
\hline Model & \multicolumn{1}{|c|}{$\mathrm{R}$} & R Square & \multicolumn{1}{c|}{$\begin{array}{c}\text { Adjusted R } \\
\text { Square }\end{array}$} & $\begin{array}{c}\text { Std. Error of the } \\
\text { Estimate }\end{array}$ & Durbin-Watson \\
\hline 1 & $.667 \mathrm{a}$ & .608 & .675 & 2.59826 & 1.871 \\
\hline
\end{tabular}

a. Predictors: (Constant), X2, X1

b. Dependent Variable: Y

Sumber: Data primer yang diolah, tahun 2019

Tabel diatas menyatakan jika nilai DW sebesar 1,871, maka untuk mengetahui ada tidaknya autokorelasi, nilai DW tersebut akan dibandingkan dengan nilai DW tabel sebagaiberikut:

Tabel 1.5

Hasil Pengujian Asumsi Klasik Autokorelasi

\begin{tabular}{|c|c|c|c|c|c|}
\hline DL & DU & 4 - DL & 4 - DU & DW & Keputusan \\
\hline 1,78469 & 1,80075 & 2,3704 & 2,21531 & 2,19925 & $\begin{array}{c}\text { Tidak ada } \\
\text { autokorelasi }\end{array}$ \\
\hline
\end{tabular}

Sumber: Data primer yang diolah, tahun 2019

Keterangan:

Nilai DW 2,19925 diperoleh dari tabel Durbin-Watson dengan ketentuan = $5 \%$, dimana $\mathrm{n}$ (sampel) $=250$ serta $\mathrm{k}$ (jumlah variabel independent $)=2$.

Dari tabel di atas dapat dilihat bahwa nilai DW sebesar 2,19925 beradadiantara nilai $\mathrm{DU}=1,80075$ dan nilai $4-\mathrm{DU}=2,19925$ ( $\mathrm{DU}<\mathrm{DW}<(4-\mathrm{DU})$ ), sehingga dapat disimpulkan bahwa dalam model regresi tidak terjadi autokorelasi atau tidak terdapat autokorelasi positif maupun negatif pada data yang diuji.

\section{Gambar 1.1}

\section{Hasil Uji Heteroskedastisitas}

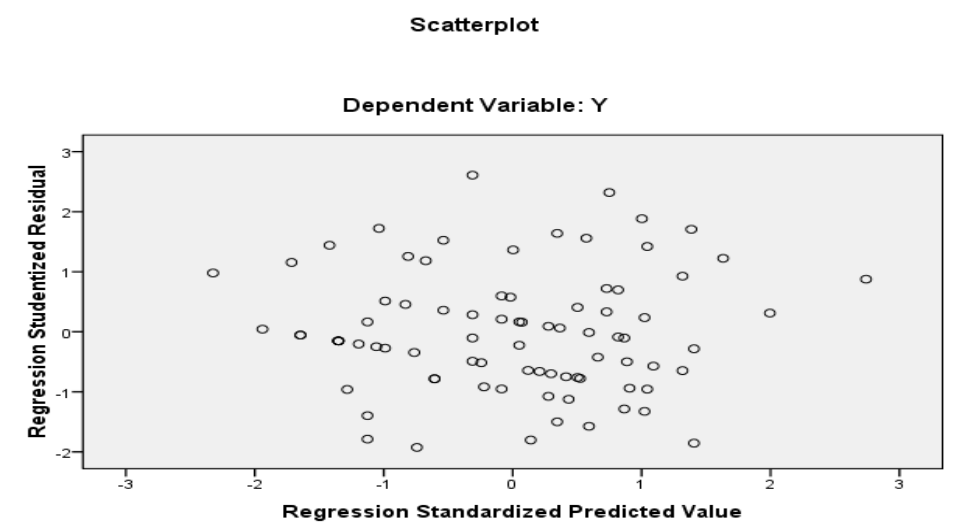

Sumber: Data primer yang diolah, tahun 2019

Dari grafik scatterplot memperlihatkan bahwa titik-titik pada grafik tidak bisa membentuk pola tertentu yang jelas, dimana titik-titik menyebar di atas dan di bawah angka 0 pada sumbu Y, sehingga grafik tersebut tidak bisa dibaca dengan jelas. Hasil ini memperlihatkan bahwa tidak terjadi heteroskedastisitas. 


\section{Gambar 1.2}

\section{Hasil Uji Normalitas}

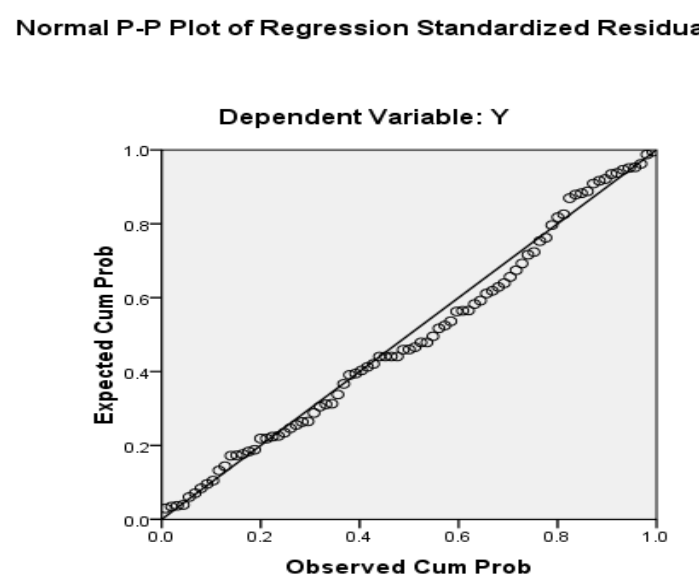

Dari hasil output SPSS di atas, pada grafik normal probability plot menunjukkan bahwa data (titik-titik) menyebar di sekitar garis diagonal dan mengikuti arah garis diagonal, maka dapat disimpulkan model regresi memenuhi asumsi normalitas.

Pada uji normalitas, jika hanya melihat hasil output grafik normal probability plot, ada kemungkinan subjektivitas dalam menginterpretasikan hasil grafik tersebut.Oleh karena itu, untuk lebih memastikan bahwa model regresi memenuhi asumsi normalitas, maka dalam penelitian ini juga dilakukan One-Sample Kolmogorov-Smirnov.Berikut hasil uji One-Sample Kolmogorov-Smirnov penelitian ini:

Tabel 1.6

Hasil Uji Kolmogorov Smirnov One-Sample Kolmogorov-Smirnov Test

\begin{tabular}{|c|c|c|}
\hline & & $\begin{array}{c}\text { Unstandardize } \\
\text { d Residual }\end{array}$ \\
\hline \multicolumn{2}{|l|}{$\mathrm{N}$} & 83 \\
\hline \multirow[t]{2}{*}{ Normal Parameters ${ }^{a}$} & Mean & .0000000 \\
\hline & Std. Deviation & 2.56638217 \\
\hline \multirow[t]{3}{*}{ Most Extreme Differe } & Absolute & .064 \\
\hline & Positive & .064 \\
\hline & Negative & -.053 \\
\hline \multicolumn{2}{|l|}{ Kolmogorov-Smirnov Z } & .580 \\
\hline \multicolumn{2}{|l|}{ Asymp. Sig. (2-tailed) } & .890 \\
\hline
\end{tabular}

a. Test distribution is Normal.

Sumber: Data primer yang diolah, tahun 2019

Berdasarkan hasil uji normalitas, diperoleh nilai signifikansi 0,580 lebih besar dari 0,05, sehingga dapat disimpulkan bahwa data berdistribusi normal.

\section{Tabel 1.7}


Hasil Analisis Regresi Linear Berganda

Coefficients $^{\mathrm{a}}$

\begin{tabular}{|c|c|c|c|c|c|}
\hline \multirow[b]{2}{*}{ Model } & \multicolumn{2}{|c|}{ Unstandardized Coefficients } & \multirow{2}{*}{$\begin{array}{c}\begin{array}{c}\text { Standardized } \\
\text { Coefficients }\end{array} \\
\text { Beta }\end{array}$} & \multirow[b]{2}{*}{$\mathrm{T}$} & \multirow[b]{2}{*}{ Sig. } \\
\hline & B & Std. Error & & & \\
\hline 1 (Constant & 16.788 & 5.722 & & 2.934 & .004 \\
\hline $\mathrm{X} 1$ & .191 & .106 & .193 & 1.800 & .000 \\
\hline $\mathrm{X} 2$ & .249 & .122 & .219 & 2.043 & .001 \\
\hline
\end{tabular}

a. Dependent Variable: Y

Sumber: Data primer yang diolah, tahun 2019

Bedasarkan hasil analisis regresi sederhana pada tabel tersebut diperoleh koefisien variabel promosi $(\mathrm{X} 1)=0,191$ dan brand image $(\mathrm{X} 2)=0,249$ serta konstanta sebesar $=16,788$ sehingga model persamaan regresi yang diperoleh dalam penelitian ini adalah sebagai berikut:

$$
\mathrm{Y}=16,788+0,191 \mathrm{X}_{1}+0,249 \mathrm{X}_{2}
$$
berikut:

Model persamaan regresi linear berganda tersebut ditafsirkan sebagai

a) $\mathrm{a}=(16,788)$ artinya variabel independen mempunyai pengaruh positif terhadap keputusan nasabah. Nilai konstanta keputusan nasabah sebesar $(16,788)$ menunjukkan bahwa semakin perusahaan memperhatikan promosi dan brand imge, maka semakin besar pengaruhnya terhadap keputusan nasabah.

b) $b_{1}=(0,191)$, Nilai koefisien regresi variabel promosi sebesar $(0,191)$ berarti jika terjadi peningkatan sebesar $1 \%$ pada variabel tersebut, maka keputusan nasabah akan meningkat sebesar 0,191atau 19,1\% dengan asumsi variabel-variabel yang lain dianggap tetap.

c) $b_{2}=(0,249)$, Nilai koefisien regresi variable brand image sebesar $(0,249)$ berarti jika terjadi peningkatan sebesar $1 \%$ pada variabel tersebut, maka keputusan nasabah akan meningkat sebesar 0,249atau 24,9\% dengan asumsi variabelvariabel yang lain dianggap tetap.

Dari hasil koefisien regresi masing-masing variabel independent (0,191 dan 0,249 ) menunjukkan bahwa variabel brand image mempunyai pengaruh yang lebih besar (dominan) dibandingkan variabel promosi terhadap keputusan nasabah tabarok pada BPRS Sarana Prima Mandiri Pamekasan.

\section{Tabel 1.8 \\ Hasil Analisis Uji F \\ ANOVA $^{b}$}

\begin{tabular}{|l|r|r|r|r|l|}
\hline Model & $\begin{array}{c}\text { Sum of } \\
\text { Squares }\end{array}$ & Df & Mean Square & $F$ & Sig. \\
\hline 1 Regression & 58.597 & 2 & 29.298 & 4.340 & .016 \\
Residual & 540.078 & 80 & 6.751 & & \\
Total & 598.675 & 82 & & & \\
\hline
\end{tabular}

a. Predictors: (Constant), X2, X1 
ANOVA $^{\text {b }}$

\begin{tabular}{|l|r|r|r|r|r|}
\hline Model & \multicolumn{1}{|c|}{$\begin{array}{c}\text { Sum of } \\
\text { Squares }\end{array}$} & Df & Mean Square & F & Sig. \\
\hline 1 Regression & 58.597 & 2 & 29.298 & 4.340 & $.016 \mathrm{a}$ \\
Residual & 540.078 & 80 & 6.751 & & \\
Total & 598.675 & 82 & & & \\
\hline
\end{tabular}

b. Dependent Variable: Y

Sumber: Data primer yang diolah, tahun 2019

Hasil uji $F$ tersebut diperoleh nilai $F_{\text {hitung }}$ sebesar 4,340 dengan tingkat signifikan sebesar 0,016 (lebih kecil dari signifikan 0,05), sedangkan nilai $F_{\text {tabel }}$ sebesar 3,879. Hal ini berarti bahwa nilai $F_{\text {hitung }} 4,340>F_{\text {tabel }} 3,879$ dan tingkat signifikan $0,016<0,05$, sehingga keputusannya yaitu variabel $X$ yang terdiri atas promosi (X1) dan brand image (X2) secara bersama-sama berpengaruh signifikan terhadap keputusan nasabah pada BPRS Sarana Prima Mandiri Pamekasan.

Tabel 1.9

Hasil Analisis Uji t

Coefficients $^{\mathrm{a}}$

\begin{tabular}{|c|c|c|c|c|c|c|}
\hline \multirow{2}{*}{\multicolumn{2}{|c|}{ Model }} & \multicolumn{2}{|c|}{ Unstandardized Coefficients } & \multirow{2}{*}{$\begin{array}{c}\text { Standardized } \\
\text { Coefficients } \\
\text { Beta }\end{array}$} & \multirow[b]{2}{*}{$\mathrm{T}$} & \multirow[b]{2}{*}{ Sig. } \\
\hline & & B & Std. Error & & & \\
\hline \multirow[t]{3}{*}{1} & (Constant) & 16.788 & 5.722 & & 2.934 & .004 \\
\hline & $\mathrm{X} 1$ & .191 & .106 & .193 & 1.980 & .000 \\
\hline & X2 & .249 & .122 & .219 & 2.043 & .001 \\
\hline
\end{tabular}

a. Dependent Variable: $Y$

Sumber: Data primer diolah tahun, 2019

Tabel 4.19 analisis uji t tersebut, pengaruh masing-masing variabel dapat dijelaskan sebagai berikut:

Variabel promosi (X1) diperoleh $t_{\text {hitung }}$ sebesar 1,980 dengan taraf sig. 0,000. Nilai $t_{\text {tabel }}$ untuk model regresi diatas yaitu 1,969. Hasil uji tersebut menunjukkan bahwa nilai signifikan $0,000<0,05$ dan nilai $t_{\text {hitung }} 1,980>t_{\text {tabel }} 1,969$. Dengan demikian dapat disimpulkan bahwa variabel promosi berpengaruh positif dan signifikan terhadap keputusan nasabah.

Variabel Brand Image (X2) diperoleh thitung sebesar 2,043 dengan taraf sig. 0,001 . Nilai tabel untuk model regresi diatas adalah 1,969. Hasil uji tersebut menunjukkan bahwa nilai signifikan 0,001 $<0,05$ dan nilai $t_{\text {hitung }} 2,043>t_{\text {tabel }} 1,969$. Dengan demikian, dapat disimpulkan bahwa variabel brand image berpengaruh positif dan signifikan terhadap keputusan nasabah.

Hal tersebut mengidentifikasikan bahwa dua variabel bebas yang dimasukkan dalam regresi, baik promosi dan brand image secara parsial berpengaruh signifikan terhadap keputusan nasabah di BPRS Sarana Prima Mandiri Pamekasan. 
Tabel 1.10

Hasil Koefisien Determinasi

Model Summaryb

\begin{tabular}{|l|r|r|r|c|}
\hline Model & \multicolumn{1}{|c|}{$\mathrm{R}$} & R Square & $\begin{array}{c}\text { Adjusted R } \\
\text { Square }\end{array}$ & $\begin{array}{c}\text { Std. Error of the } \\
\text { Estimate }\end{array}$ \\
\hline 1 & $.667^{\mathrm{a}}$ & .608 & .675 & 2.59826 \\
\hline
\end{tabular}

a. Predictors: (Constant), X2, X1

b. Dependent Variable: Y

Sumber: Data primer diolah dengan SPSS, 2019

Hasil analisis data tersebut terlihat bahwa besarnya Adjust $R^{2}$ adalah 0,675 atau $67,5 \%$. Hal ini berarti sebesar $67,5 \%$ kemampuan model regresi pada penelitian ini dalam menerangkan variabel dependen. Artinya $67,5 \%$ variabel keputusan nasabah dijelaskan oleh variasi variabel independen yang terdiri atas promosi dan brand image. Sedangkan, sisanya $(100 \%-67,5 \%=32,5 \%)$ dipengaruhi oleh variabel-variabel lainnya yang tidak diperhitungkan dalam analisis penelitian ini.

Berdasarkan Hasil di atas uji $\mathrm{F}$ diperoleh nilai $\mathrm{F}_{\text {hitung }}$ sebesar 4,340 dengan tingkat signifikan sebesar 0,016 (lebih kecil dari signifikan 0,05), sedangkan nilai $F_{\text {tabel }}$ sebesar 1,703. Hal ini berarti bahwa nilai $F_{\text {hitung }} 4,340>F_{\text {tabel }} 1,703$ dan tingkat signifikan $0,016<0,05$, sehingga keputusannya yaitu variabel $\mathrm{X}$ yang terdiri atas promosi (X1) dan brand image (X2) secara bersama-sama berpengaruh signifikan terhadap kepuatusan nasabah pada BPRS Sarana Prima Mandiri Pamekasan.

Penelitian Yesi (2004) "pengaruh citra merek dan promosi penjualan terhadap keputusan nasabah memilih tabungan bank syariah mandiri." 24

Agar bisa berhasil dalam bisnis yang kompetitif, pelaku bisnis harus menawarkan promosi yang tepat dengan pelayanan yang berstandart sehingga akan memberikan kepuasan pada nasabah dengan kata lain promosi dan kualitas layanan memberikan pengaruh terhadap kepuasan nasabah. ${ }^{25}$

Seorang pemasar akan berhasil dalam komunikasinya jika mampu memberikan informasi benar. Respon atau tanggapan konsumen sebagai komunikan yang diharapkan oleh pemasar yaitu membentuk kesadaran informasi tertentu (kognitif), memberikan pengaruh untuk melakukan sesuatu berupa pembelian produk (afeksi) dan membentuk perilaku konsumen berupa pembelian ulang (behavior). ${ }^{26}$ Artinya promosi (komunikasi) dapat mempengaruhi keputusan nasabah sehingga akan tercipnya kesadaran informasi tertentu dan pembelian ulang pada suatu produk.

BPRS Sarana Prima Mandiri Pamekasan menghadirkan mobil kas keliling guna untuk memberikan layanan dan promosi kepada nasabahnya dengan tujuan untuk meakukan pembelian (keputusan nasabah). Mobil kas keliling digunakan untuk melayani nasabah tabarok dalam melakukan penarikan maupun penyetoran secara tunai. Selain itu mobil kas keliling dapat digunakn untuk mempromosikan produk atau layanan yang ada pada BPRS Sarana Prima Mandiri Pamekasan.

Berdasarkan hasil penelitian yang dilakukan oleh peneliti, BPRS Sarana Prima Mandiri Pamekasan melakukan promosi dengan cara menawarkan iklan yang

${ }^{24}$ Adiya Bagus Indratama dan Yesi Artanti, "pengaruh citra merek dan promosi penjualan terhadap keputusan nasabah memilih tabungan bank syariah mandiri," Junal IImu Manajemen, vol 2 nomor 4 (4 oktober 2014)

${ }^{25}$ Ahmad Subagyo, Marketing in Business (Jakarta: Mitra Wacana Media, 2010), 132-134.

${ }^{26}$ Fajar Laksana, Manajemen Pemasaran: Pendekatan Praktis (Yogyakarta: Graha Ilmu, 2008), 134. 
menarik, melakukan promosi lewat radio, melakukan promosi yang dilakukan di bazaar expo, melakukan promosi diluar jam operasional (sabtu malam/night market), menyediakan website resmi dan hotline call untuk memudahkan nasabahnya dalam memperoleh informasi, melakukan promosi dengan cara mendatangi nasabah atau lembaga (personal selling).

Dilihat dari pelayanan yang diberikan oleh petugas mobil kas keliling BPRS Sarana Prima Mandiri Pamekasan ketika peneliti melakukan penelitian, petugas mobil kas keliling sudah memberikan layanan yang sesuai dengan keinginan nasabah seperti mobil kas memiliki tampilan yang menarik, profil petugas yang ramah dan rapi, kesedian petugas mobil kas keliling dalam membantu nasabah, petugas mobil kas keliling memahami kebutuhan nasabah, kemudahan dalam bertransaski menggunakan mobil kas keliling, menyediakan jasa atau layanan sesuai yang dijanjikan, transaksi menggunakan mobil kas keliling terbilang cepat karena tidak perlu mendatangi kantor untuk bertransaksi, kecekatan petugas dalam melayani nasabah, terdapat nomor kontak yang bisa dihubungi oleh nasabah, serta petugas memiliki sifat yang bisa dipercaya.

Sedangkan berdasarkan hasil analisis data diperoleh besarnya Adjust $R^{2}$ sebesar 0,675 atau 67,5\%. Hal ini berarti sebesar 67,5\% kemampuan model regresi pada penelitian ini dalam menerangkan variabel dependen. Artinya $67,5 \%$ variabel keputusan nasabah dijelaskan oleh variasi variabel independen yang terdiri atas promosi dan brand image. Sedangkan, sisanya $(100 \%-67,5 \%=32,5 \%)$ dipengaruhi oleh variabel-variabel lainnya yang tidak diperhitungkan dalam analisis penelitian ini.

Sebagaimana diketahui bahwa BPRS Sarana Prima Mandiri Pamekasan telah memiliki produk unggulan yaitu produk pembiayaan TABAROK. Nasabah tabarok inilah yang banyak menikmati kehadiran mobil kas keliling SPM, karena target market dari pembiayaan ini memang menyasar kepada masyarakat kecil yang ada di pasar-pasar diseluruh pelosok. Mobil kas keliling memiliki jam dan jadwal operasional setiap harinya yaitu dari jam 08.00-10.00 digunakan untuk melayani pembiayaan Tabarok, dari jam 10.00-12.00 digunakan untuk kegiatan funding dan setelah itu bisa digunakan untuk sosialisasi ke lembaga-lembaga sebagai bentuk promosi. Jadwal operasionalnya yaitu hari senin berlokasi di pasar gurem, hari selasa di pasar pagendingan, hari rabu di pasar kepo, hari kamis di pasar 17 agustus dan hari jum'at di pasar blumbungan. Tidak hanya itu, mobil kas keliling juga beroperasi pada malam minggu yang berlokasi di monument arek lancor dari jam 19.00-22.00 (Night Bank) yang hampir semuanya pedakang kaki lima disana menggunakan pembiayann Tabarok.

Adapun berdasarkan hasil uji $t$, variabel promosi (X1) diperoleh $t_{\text {hitung }}$ sebesar 1,980 dengan taraf sig. 0,000. Nilai t tabel untuk model regresi diatas yaitu 1,969. Hasil uji tersebut menunjukkan bahwa nilai signifikan $0,000<0,05$ dan nilai $t_{\text {hitung }} 1,980>t_{\text {tabel }} 1,969$. Variabel brand image (X2) diperoleh $t_{\text {hitung }}$ sebesar 2,043 dengan taraf sig. 0,001. Nilai $t_{\text {tabel }}$ untuk model regresi diatas adalah 1,969 . Hasil uji tersebut menunjukkan bahwa nilai signifikan 0,001 $<0,05$ dan nilai thitung 2,043> $t_{\text {tabel }}$ 1,969. Hal tersebut mengidentifikasikan bahwa dua variabel bebas yang dimasukkan dalam regresi, baik promosi dan brand image secara parsial berpengaruh signifikan terhadap keputusan nasabah di BPRS Sarana Prima Mandiri Pamekasan. Dengan demikian dapat disimpulkan bahwa variabel brand image lebih berpengaruh (dominan) terhadap keputusan nasabah tabarok pada BPRS Sarana Prima Mandiri Pamekasan.

Pada penelitian Restu (2017) "pengaruh brand image dan promosi terhadap nasabah memilih produk asuransi syariah" yang berpengaruh positif dan signifikan 
terhadap keputusan nasabah memilih produk asuransi syariah di PT asuransi jiwa syariah lampung". 27

Keputusan pembelian konsumen adalah pemilihan suatu tindakan dari dua atau lebih pilihan alternatif keputusan. Seorang konsumen yang hendak melakukan pilihan harus memiliki pilihan alternatif. Keputusan konsumen dalam mengambil adalah pemilihan dari dua atau lebih alternatif pilihan keputusan pengambilan produk, artinya bahwa seseorang dapat membuat keputusan, haruslah tersedia alternatif lainnya. Keputusan pembelian menurut Kotler dan Keller adalah proses yang harus dilewati oleh konsumen melalui lima tahap yaitu pengenalan kebutuhan, pencarian informasi, evaluasi alternatif, keputusan pembelian dan perilaku pasca pembelian yang jauh sebelum konsumen actual dilakukan dan memilki dampak yang lama setelah itu. ${ }^{28}$

BPRS Sarana Prima Mandiri Pamekasan menghadirkan mobil kas keliling untuk memberikan layanan kepada masyarakar yang merupakan bagian dari strategi yang dilakukan oleh BPRS Sarana Prima Mandiri Pamekasan untuk memberikan kepuasan kepada nasabahnya. Dari layanan mobil kas keliling ini, masyarakat bisa melakukan transaksi secara langsung baik untuk melakukan panarikan maupun penyetoran uang secara tunai.

Demi kemudahan nasabahnya, maka BPRS Sarana Prima Mandiri Pamekasan menerapkan layanan mobil kas keliling, dimana petugas mobil kas keliling mendatangi nasabah yang ingin melakukan transaksi ke tempat mereka bekerja seperti ke pasar. Hal tersebut sangat memudahkan nasabah dalam bertransaksi agar tidak perlu repot-repot meluangkan waktunya untuk datang ke kantor BPRS Sarana Prima Mandiri Pamekasan, sehingga dengan layanan mobil kas keliling, nasabah merasa terbantu yang nantinya akan berdampak pada kepuasan nasabah. Mobil kas keliling tidak hanya beroperasi pada hari kerja, tetapi pada akhir pekanpun nasabah bisa menggunakan layanan mobil kas keliling (night bank) yang berlokasi di areal monumen arek lancor pamekasan.

Dilihat dari pelayanan yang diberikan oleh petugas mobil kas keliling BPRS Sarana Prima Mandiri Pamekasan ketika peneliti melakukan penelitian, petugas mobil kas keliling sudah memberikan layanan yang sesuai dengan keinginan nasabah seperti mobil kas memiliki tampilan yang menarik, profil petugas yang ramah dan rapi, kesedian petugas mobil kas keliling dalam membantu nasabah, petugas mobil kas keliling memahami kebutuhan nasabah, kemudahan dalam bertransaski menggunakan mobil kas keliling, menyediakan jasa atau layanan sesuai yang dijanjikan, transaksi menggunakan mobil kas keliling terbilang cepat karena tidak perlu mendatangi kantor untuk bertransaksi, kecekatan petugas dalam melayani nasabah, terdapat nomor kontak yang bisa dihubungi oleh nasabah, serta petugas memiliki sifat yang bisa dipercaya.

\section{Kesimpulan}

Berdasarkan hasil analisis data dan pengujian hipotesis tentang "Pengaruh Promosi dan Brand Image Terhadap Keputusan Nasabah dalam Memilih Pembiayaan Tabarok pada BPRS Sarana Prima Mandiri Pamekasan", maka dapat ditarik kesimpulan sebagai berikut:

1. Berdasarkan hasil uji $\mathrm{F}$ diperoleh nilai $F_{\text {hitung }}$ sebesar 4,340 dengan tingkat signifikan sebesar 0,016 (lebih kecil dari signifikan 0,05), sedangkan nilai $F_{\text {tabel }}$ sebesar 1,703. Hal ini berarti bahwa nilai $\mathrm{F}_{\text {hitung }} 4,340>\mathrm{F}_{\text {tabel }} 1,703$ dan tingkat signifikan $0,016<0,05$, sehingga keputusannya yaitu variabel $\mathrm{X}$ yang terdiri atas promosi (X1) dan brad image (X2) secara bersama-sama berpengaruh signifikan terhadap keputusan nasabah pada BPRS Sarana Prima Mandiri Pamekasan.

27 Restu Setiawan(2017) "pengaruh brand image dan promosi terhadap nasabah memilih produk asuransi syariah”. i.

28 Philip Kotler dan Kevin Lane Keller, Manajemen Pemasaran Jilid1 edisi 13, 195. 
2. Berdasarkan hasil analisis data terlihat bahwa besarnya Adjust $R^{2}$ adalah 0,675 atau $67,5 \%$. Hal ini berarti sebesar $67,5 \%$ kemampuan model regresi pada penelitian ini dalam menerangkan variabel dependen. Artinya 67,5\% variabel keputusan nasabah dijelaskan oleh variasi variabel independen yang terdiri atas promosi dan brand image. Sedangkan, sisanya $(100 \%-67,5 \%=32,5 \%)$ dipengaruhi oleh variabel-variabel lainnya yang tidak diperhitungkan dalam analisis penelitian ini.

3. Berdasarkan Hasil uji $t$, variabel promosi (X1) diperoleh $t_{\text {hitung }}$ sebesar 1,980 dengan taraf sig. 0,000. Nilai tabel untuk model regresi diatas yaitu 1,969. Hasil uji tersebut menunjukkan bahwa nilai signifikan 0,001 $<0,05$ dan nilai thitung 1,980 > $t_{\text {tabel }}$ 1,969.Variabel brand image (X2) diperoleh $t_{\text {hitung }}$ sebesar 2,043 dengan taraf sig. 0,001. Nilai $t_{\text {tabel }}$ untuk model regresi diatas adalah 1,969. Hasil uji tersebut menunjukkan bahwa nilai signifikan 0,001 < 0,05 dan nilai $t_{\text {hitung } 2,043>}$ $t_{\text {tabel } 1,969}$. Hal tersebut mengidentifikasikan bahwa dua variabel bebas yang dimasukkan dalam regresi, baik promosi dan brand image secara parsial (individual) berpengaruh signifikan terhadap keputusan nasabah di BPRS Sarana Prima Mandiri Pamekasan. Dengan demikian dapat disimpulkan bahwa variabel brand image lebih berpengaruh (dominan) terhadap keputusan nasabah tabarok pada BPRS Sarana Prima Mandiri Pamekasan.

\section{DAFTAR PUSTAKA}

Ahmad Subagyo, Marketing in Business. Jakarta: Mitra Wacana Media, 2010.

Adiya Bagus Indratama dan Yesi Artanti, pengaruh citra merek dan promosi penjualan terhadap keputusan nasabah memilih tabungan bank syariah mandiri. Junal Ilmu Manajemen, vol 2 nomor 4 (4 oktober 2014).

Buchari Alma, Manajemen Pemasaran dan Pemasaran jasa. Bandung: Alfabeta, 2011.

Bilson Simamora, Riset Pemasaran, Falsafah, Teori, Dan Aplikasi. Jakarta : PT Gramedia Pustaka Utama, 2004.

Fajar Laksana, Manajemen Pemasaran: Pendekatan Praktis. Yogyakarta: Graha Ilmu, 2008.

Fatati Nuryana, Statistik Bisnis Jilid 1. Surabaya: Pena Salsabila, 2013.

Freddy Rangkuti, The Power of Brand Teknik Mengelola Brand Equity dan Strategi Pengembangan Merek. Jakarta, PT Gramedia Pustaka Utama, 2002.

Husein Umar, Metode Penelitian Untuk Skripsi dan Tesis Bisnis Edisi Kedua. Jakarta: Rajawali Pers, 2013.

Imam Ghazali, Aplikasi Analisis Multivariate Dengan Program SPSS. Semarang: Badan Penerbit Universitas Diponegoro, 2001.

Iqbal Hasan, Analisis Data Penelitian Dengan Statistik. Jakarta : Bumi Aksara, 2010.

Jonathan Sarwono dan Ely Suharyati, Riset Akuntansi Menggunakan SPSS. Yogyakarta: Graha Ilmu, 2010.

Misbahuddin dan Iqbal Hasan, Analisis Data Penelitian dengan Statistik ed. 2. Jakarta: PT. Bumi Aksara, 2013.

Mudrajat Kuncoro, Metodologi Kuantitatif. Yogyakarta: Sekolah Tinggi Ilmu Managemen YKPN, 2011

Purbaya Budi Santosa, Azhari, Analisis Statistic Dengan Microsof Excel Dan SPSS. Yogyakarta: ANDI, 2005. 
Luluk Farhatin Istiana, Rudy Haryanto

Riduan, Dasar-Dasar Statistika. Bandung: Alfabeta, 2009.

Sugiyono, Metode Penelitian Kuantitatif, Kualitatif dan R\&D. Bandung: Alfabeta, 2009 